\title{
THE AVATARS OF THE WORD IN ROMANIAN POSTMODERN POETIC DISCOURSE
}

\section{Elena DULGHERU*}

\begin{abstract}
Poetry is the freest of the arts, because it is the least related to a material support. In an era in which arts are increasingly subservient to technology, poetry remains the art that is the least subject to industrialization. Being the least dependent on technology, poetry is the most direct art, the art that reflects most faithfully the aspirations of the creator's ego. Therefore, poetry is, at least since modernity, the first of the arts that reflects the creative spirit's trends of a particular era. Progressive industrialization of society has deepened this feature. Thus, poetry is the first of the arts that most directly reflects "the avatars of the image", specific to postmodern phenomenology. The study explores the changing of the poetic paradigm in Romania during the second half of the $20^{\text {th }}$ century, and thus the paradigm shift regarding the social responsibility of the poet. However, this paradigm shift has not cancelled the classical poetic paradigm, but has just put it into the shade. From this shade, the classic paradigm of the creator ego launches challenges to the postmodern paradigm, as in an invisible war led on the territory of arts. This invisible war concerns us in this study. Offeringfew brief comments on some trends in Romanian poetry, from the postwar period to the present, from the fracturiste movement to religious and mystical poetry, we try to detect the anthropological creative model that underpins them. For the creative act is determined, beyond the factual material and the ideas of an epoch, by the relationship of the creative ego with himself, his fellowmen and with God. Ultimately, poetic creation highlights the relationship of the creative ego with the Divine Logos: a relationship either of dialogue, or corrupted by the isolationist or even sacrilegious monologue of the artist.
\end{abstract}

*Film-critic, film journalist, Ziarul Lumina, Bucharest, Romania. 
Keywords: literary trend, paradigm of creative self, unseen war, fracturism, mystagogical art

\section{Introduction: What is Poetry? The Classical Paradigm}

In order to understand the situation of contemporary poetry, we should remind ourselves of the essence of poetic creation in its classic paradigm and changes to this paradigm from classicism to modernism and postmodernism.

In its essence, poetry is the freest of the arts, because it is the least related to a material support. In our times, when arts are increasingly subservient to technology, poetry remains the art that is the least subject to industrialization. Being the least dependent on technology, poetry is the most free art and the art that most faithfully reflects the inner aspirations of the creator's ego. Therefore, at least since modernity, poetry has been the art that best reflects the trends of the creative spirit and the state of mind of a particular epoch. Progressive industrialization of society has deepened this feature. Thus, poetry is the art that most directly reflects "the avatars of the (sacred) image", a fact that is specific to the phenomenology of postmodernity. So, until nowadays, poetry is the best spiritual barometer of an epoch, and the best indicator of the relationship between the individual and the symbolic world in a certain cultural epoch. This desemantisation, that is, the break of the relation with the symbol, specific to the phenomenology of postmodernity, is particularly accurately reflected in contemporary poetry.

This substantial change of paradigm from classicism to modernism and postmodernism is closely bound with the change of the paradigm of the author. The role and social responsibility of the writer, especially of the poet, has radically changed in the last three centuries.

The classical (or so-called traditional) paradigm, issued in Greek Antiquity, considers the poet to be a prophet, visionary, minstrel, and spiritual educator of society. His moral influence and contribution to the coagulation of local and national cultures were very significant. Such models have crystallized in Greek and Roman Antiquity, and they continued in the European Middle Ages, up to Romanticism; but we find them practically the same in Eurasian and Far Eastern cultures and everywhere in traditional cultures. This classical model penetrated with 
minimal changes until the late 19th and early 20th century in Europe, up to the literary avant-garde trends.

This quasi-sacerdotal elevation of the author, proclaimed in Antiquity, continued almost unchanged until modernity. We can enumerate consistent lists of very different landmark authors, from very different epochs and cultures (from Homer and Ovidius to Hafiz, from Petrarca, Shakespeare, Goethe, Byron and Victor Hugo, to Shota Rustaveli, Sayat Nova and the japanese Basho, from Pushkin and Lermontov to Eminescu and Lucian Blaga). Their common denominator is artistic genious, materialized in the ability to access and synthesize permanent spiritual values, but also civic consciousness, a feeling of responsibility for the peoples and countries to which they belonged, and sometimes a responsibility for the whole of humankind. Sometimes the image of the prophet-poet was replaced by that of the citizen-poet or the poet-as-a-hero, or all three were joined into a single image of the exemplary poet, the poet par excellence (like Byron, Sayat Nova, both Pushkin and Lermontov, and Eminescu). That's why their strong artistic personalities were able to irradiate through ages and cultural borders, and to enrich with elevated ideals the cultural and moral climate of their epoch, and even of subsequent ages.

\section{A More Recent History of (East-European) Poetry}

\subsection{The Conservation of the Traditional Paradigm}

Even in the 20th century, important artists, especially poets and writers, have morally supported, with their talent, courage and personalities, resistance against totalitarian regimes from Cuba to Spain, Eastern Europe and Africa. Many of them have paid a high price for their heroism; in Eastern Europe, especially during the years of the Bolshevik Dictators (like Anna Akhmatova, Marina Tsvetaeva, Boris Pasternak in the USSR, Ciabua Amiredjibi in Soviet Georgia, Radu Gyr, Sandu Tudor, Dinu Pillat, Nichifor Crainic and other poets of the communist prisons in Romania, and so on).

But the model of the citizen-poet did not disappear together with the violent opression of the totalitarian regimes. It survived in the period of political thaw, when opression was not as evident, but was still present, 
being perceived through the censorship, which controlled all the fields of the culture. During the political thaw of the seventies in Romania and Perestroika of the eighties in the USSR, the dissident poets and writers and the bard-poets appeared (like Bulat Okudzhava and Vladimir Vysotski in the USSR, Václav Havel in Czechoslovakia, Adrian Paunescu and Ana Blandiana in Romania, and so on). Despite the fact they dared to criticise the regime in their poems and songs (a courage that previously had been paid for with jail time or even with the lose of life), they were tolerated by the communist regime, as long as their critique was benign, that it was moderated and did not manifest too often; and as long as their critique did not urge social rebellion, but only a certain revival of society and exit from the lethargy, into which the brutality of the proletcultist regime had thrown it. In order to protect their image of democratic regimes (so-called 'socialist democracies'), the communist ideological apparatuses realized that they needed the disident poets and bards. It is true that some of them had to make small compromises with the regime, but still kept their voices, their identities and abilities to inspire the masses. This period of relative freedom of expression in the Eastern Block led to synchronization with the Western European artistic trends.

In Romanian poetry, this led to the birth of the generation of the eighties, which was nourished from a civic and artistic paradigm, that was radically different from that of the 'citizen-poets'. They were anti-heroic, apolitical, not socially subservient, and were allergic to the so-called 'engaged art', but also to the humanist and metaphysical ideals of the previous generations. They cultivated the so-called 'concrete poetry', as the artists inspired by pop art and abstract expressionism cultivated concrete art. This was a fragmentary poetry, operating with fragments of reality, drawn from the immediate proximity of the poet, and cut off from any symbolic or metaphysical connection. It was a pseudo-automatic dictee, close to what was practiced by some avant-garde poets, but lacking the enthusiasm and the overflowing eccentricities of the former. The forthcoming poetic trend of fragmentarism will inspire from here.

\subsection{The Opposite, Anti-iconic Paradigm}

The situation has radically changed since the fall of communism in the Eastern-European Block: since freedom of speech was now for 
all, the dissident artist and the hero-poet were no longer needed! Their myth increased for a short time, together with the declassification of the security records, but declined gradually and irreversibly. After the ' 90 s, the model of the 'citizen-poet' hopelessly fell into desuetude. The prominent poetic personalities of the sixties and the seventies (like Marin Sorescu, Ştefan-Augustin Doinaș, Cezar Ivănescu, Mircea Ivănescu, Ioan Alexandru, Dan Verona) were still active and influential, but were growing old, and, step by step, some of them physically disappeared from the literary scene, or felt into silence (like Dan Verona). So, their place was taken by newcomers. A few 'veterans' succeeded at adapting to the new epoch of freedom of expression generated by the social and politic freedoms (like Nora Iuga, Ana Blandiana, Mircea Dinescu - for a short time). The best adapted were those whose poetic program did not contain political or social goals. But even so, after the ' $90 \mathrm{~s}$ the public audience of the poetic discourse considerably diminished. And, despite the freedom to publish, circulation and visibility of the books and magazines that published poetry considerably decreased.

The generation of the eighties, continued with 'the poets of the nineties' and the so-called 'poets of the year two thousand' ('douămiiști'), expressed now freely in post-communist Romania, practically without any ideological or artistic opposition. Despite the fact that they are not distinguished too much from each other, and that they never gained a numerous public following, they gradually conquered the university chairs, the editorial boards of the literary magazines, penetrated into the juries of poetry contests and into the organising boards of the new-born poetry festivals. All this tacit, but rather aggressive self-promotion was made under the banner of generational cliques (in accordance with the unwritten law "who is not with us is against us"), and not on the basis of the artistic abilities of the new poets or of their power of vision - attributes, which they programmatically avoided, for the simple reason that they (the attributes) would have disqualified them. So, gradually, they became the most visible and internationally promoted Romanian poets, the official trend and landmark of contemporary Romanian poetry abroad. And all these outcomes came under the banner of no political or social commitment, and under a dogma of artistic laxity and 'democracy', as 
pretended forms of freedom of thought and expression.

\section{Two Case Studies of the Anti-iconic Paradigm}

\subsection{Marius Ianuș, Dumitru Crudu and "The Fracturist Manifesto"}

But how sound is this dogma? Of course, there is not a unique code. Here is, for example, a fragment of a manifesto of the generation of 'nineties' ("nouăzeciști'), "The Fracturist Manifesto", signed by the poets Marius Ianuș and Dumitru Crudu, the initiators of the 'fracturist' trend in Romania. It was initially published in Monitorul de Braşov in October $1981^{1}$.

"It's a current that we inaugurated - D.C. and M.I. - on the night of 10th to 11th September ' 98 (when we were beaten on the street), to finish with poetry. Since then, our writings have been called fractures. When we first published this text we did not have time to make a radiograph of the current, but just to describe it in general terms [...].

Fracturism has several levels: socio-cultural, psychological, aesthetic, and as a consequence, our current is the literary reflection of a new reality. Politically it is represented by anarchism. Our anarchy is the revolt of more or less false Marxists who see how fucking fascists like Fukuyama plead for a world that destroys the spiritual values of humanity. It's better that we should destroy the world.

In order to give the simplest example of the fracture of the message in the world we live in: in different registers, it is a fracture between a miserable movie from a TV channel and the awkward commercials that interrupt it. It is normal for these cracks, which are visible to the naked eye, to be reflected in writing. Our brain works (if it does) like the world we live in."

Like most literary manifestoes of the 20th century (much less those of the 21st century), it is full of pretentious and radical formulas, contradicting each other, of authorial vanities and a spirit of revenge against the previous generation, that of the 'poets of the eighties', but it also contains some autobiographical inaccuracies or mystifications.

1 Dumitru CRUdu, Marius IANUŞ, "Manifestul Fracturist", ziarul Observator de Constanţa, no. 85-86/5 iunie 2001, http://asalt.tripod.com/a_086.htm (Accessed at 10.04.2017).

2 Ibidem. 
ARS LITURGICA. From the Image of Glory to the Images of the Idols of Modernity

However, it was treated seriously by the literary critics, who did not note the abundant and hilarious 'logical fractures' of the "Fracturist Manifesto".

For example, the trend claims to be apolitical, more precisely, 'anarchist', but repeatedly uses Marxist terminology, criticizing the 'petty bourgeois' spirit of the generation of its predecessors. The current generation criticizes the previous generation of poets for their "outdated, but fixed ideas", but invokes Marxist ideas, which are also 'fixed' for those who cultivate them now, especially in Eastern post-communist Europe, and also 'outdated', since the generation of Louis Aragon and Vladimir Maiakovski (to whom the authors of the 'Manifesto' even do not refer, to define their separation). Ignoring its illustrious, but forgotten predecessors, so, the ideological reality from which it issues, the current generation pretends to be "a literary reflection of a new reality". So, like other postmodern sub-trends, it ignores his predecessors during the historical Avant-garde movement, identifying only its synchronous influences (contemporary Polish and EasternEuropean poetry in general). The authors of the Manifesto believe that Fracturism was "the first model of a radical break to postmodernism", ignoring their affiliation de facto to this meta-current, since they define it as cultivating the fragmentation and the concrete, immediate reality essential features for postmodernism. Finally, the authors of the Manifesto exhibit a typical and non-original allergy to culture as a source of poetic creation, as did all the Avant-gardists, ignoring, once again, their historical predecessors.

And the examples of logical inadvertencies and lack of originality can continue. But that isn't the problem. The problem is that, under this mask of opportunism with Marxist polishing, hides the egoistic cult of auctorial, limited ego and the cult of the sensorial reality, as the only reality, both raised to the rank of literary dogma, ignoring man's connection with the universe, with his ancestors, and ultimately with the Divine. All these small impostures or sightlessnesses lead, in the plan of artistic creation, to the loss of the iconic dimension of the poetry.

Here are more arguments for this conclusion, extracted from the texts of the second signatory of the Manifesto, the Bessarabian poet Dumitru Crudu. As the renowned literary critic Marin Mincu observes, Dumitru Crudu states that "fracturism ... considers that no sacrament is 
hidden in everyday life" and "refuses to bind the immediate to a mythological world", since "nothing can no longer be related to other things, because only what can be seen exists"3.

This iconoclastic, anti-metaphysical and antireligious perspective is fully valorised by Marius Ianuș, a poet who will later have the power to embrace faith and even become a brother in an Orthodox monastery ${ }^{4}$; but we are not referring to the religious age of his life here, but to his debut period, which was fully enrolled in the Romanian postmodern trends (assumed or not as such) of the years 1999-2000. His poetic approach from the first two volumes, which imposed him, entitled "Hartie igienica" (Hygienic Paper, 1999) and "Manifest anarhist si alte fracturi" (Anarchist Manifesto and Other Fractures, (2000), has been analyzed by the literary critic Mihai Iovănel. He compares Marius Ianuş's writing with that of the American poet Allen Ginsberg", observing his "broad rhetoric, based on [...] a shocking, ideological, paranoid sincerity" [...]. In particular, a sequence of the first poem, entitled 'Romania', from his second volume, "provoked scandal, given the hardcore erotic register in which the poet, simultaneously projected in the violator and the vulnerable victim, approximates the image of the homeland, as Ginsberg in his poem 'America' - comments the literary critic.

"Such verses and others, even stronger, although preceded by poets like Daniel Banulescu and Mihai Gălățanu, provoked numerous outraged reactions [...] Marius Ianuş' character is disputed relatively equally by neuropathy, uncensored aggression and chronic depression, by social and sexual fantasies: a member of the generation lost in the dawn of the post-communist transition, practicing self-analysis in the form of "shameful songs". The critics were, in the first instance, disoriented by the self-referentiality of Marius Ianus, who introduces in

3 Marin MiNCU, "Fracturismul poetic - o negaţie neoavangardistă a optzeciştilor", "Suplimentul de marți al ziarului "Observator" de Constanța", http://asalt.tripod.com/ a_086.htm /(Accessed on 10.04.2017).

4 Marius IANUȘ, "De la Fracturism la Dumnezeu. Rezumatul conferinţei ţinută la Biblioteca Bucovinei din Suceava”, https://yanush.wordpress.com/2012/03/16/de-lafracturism-la-dumnezeu (Accessed on 10.04.2017).

${ }^{5}$ An american poet, a leading figure of the Beat Generation and an energic promoter of the homosexuals' rights. 
ARS LITURGICA. From the Image of Glory to the Images of the Idols of Modernity

his verses, in a hip-hop style, the most trivial sketches of personal reality." 6

\subsection{The Case of Mihai Gălățanu}

Another case, typical of the deformation, up to mutilation and sacrilege, of the word, of the image of man, of homeland and of God, is that of Mihai Gălățanu. Debuted in 1983 and holder of two national poetry awards, the poet gained visibility as a result of the scandal caused by his volume "O noapte cu Patria și România cu prostii" (A Night with Motherland and Romania with Rubbish), published by Vinea, the most prestigious Romanian poetry publishing house, in 2001. The violent suburban vocabulary and the dense pornographic imagery, attacking the image of love, of the woman, and of Motherland, made the tour of the literary press of the time. The poet, supported by the most influential critics, like Nicolae Manolescu, Alex Stefănescu and Gheorghe Grigurcu, was friendly labeled as 'satanist' by the critic Octavian Soviany, one of his influential admirers. This only increased Gălățanu's prestige among the most influential poets and critics. "On the anniversary of the poet's birthday, organized by Vinea Publishing House on September 11, 2013, the critic Octavian Soviany 'amusedly' said: "I met Gălăţanu at the 'Euridice' literary circle, headed by Marin Mincu... I read his poems, I really liked them... yes, I made you a satanist!"”.

All these increased his prestige and opened to him the doors to the most comfortable positions of the literary world. For reasons of decency, the quoting of his lyrics within an academic setting is impossible.

However, even his former defender, Alex Ştefănescu reveals the increasingly abusive sacrileges used by Mihai Gălăţanu to maintain his top position on the front page of literary magazines. The critic asserts:

${ }^{6}$ Mihai Iovanel, "Marius Ianuș, de la 'hârtie igienică' la 'fularul alb', Revista Cultura, nr. 347/27.10.2011, http://revistacultura.ro/nou/2011/10/marius-ianus-de-la-\%E2\% 80\%9Ehartie-igienica\%E2\%80\%9C-la-\%E2\%80\%9Efularul-alb\%E2\%80\%9C/ (accessed in 10.04.2017).

7 Claudia Minela, "Mihai Gălăţanu îşi aniversează ziua cu prietenii, amintindu-şi”, Bocancul literar.ro, undated, http://www.bocancul-literar.ro/Forms/CreatieLiterara/ DetaliiCreatie.aspx?id=28676 $($ accessed in 10.04.2017). 
"The title of Mihail Gălăţanu's last book, 'Memorialul plăcerii' (engl.: The Memorial of Pleasure) is an impiety. The author makes a cheap game of words starting from a TV series ${ }^{8}$, that shook consciousness. The title was taken from a poem in which Mihail Gălăţanu, equally uninspired, finds a similarity between the paroxystic voluptuousness, generating groans, of sexual intercourse, and the tortures of the political prisoners in the communist prisons [...] The author has specialized in writing such texts to scandalize readers. He has done, as it is known, even from the Homeland, the heroine of an imaginary pornographic film, drawing upon him the anger of public opinion. Recently, a police officer even wanted to prosecute him, but the literary world promptly reacted, defending the terrifying poet". 9

What was the argument of his defendors ? Of course, freedom of speech. But this freedom was no longer used with the risk of personal liberty, in the interest of the community (as once, by the great poetsheroes, quoted at the beginning of this work), but in strictly personal and selfish interests.

\section{Conclusion}

Unfortunately, on the background of social depression and moral disorientation of the Romanian post-decembrist transition, both quoted cases created numerous precedents in recent poetry. They even provoked in young poets the belief that injuries to human, moral and national values, are a firm tip for literary success. This has increased the climate of uncertainty, devoid of values and decadence of today's Romanian literature.

Fortunately, however, this dangerous paradigm shift did not cancel out the classical poetic paradigm, but only has put it into the shade. From this shade, the classical paradigm of the creator launches challenges to the postmodern paradigm, as in an invisible war, a spiritual war, led on the territory of arts.

Fortunately, there is another trend in Romania, of mystical-

${ }^{8}$ Lucia Hossu-Longin, "Memorialul durerii", Romanian Television (TVR).

9 Alex Ștefănescu, "Mihail Gălăţanu și-a pierdut răbdarea", România Literară, no. 36/2000, http://www.romlit.ro/mihail_glanu_i-a_pierdut_rbdarea (accessed in 10.04.2017). 
religious poetry, written in diverse styles, but fed from authentic values. It remained in the shadow both in the socialist period and after 1989. The religious poets, almost voiceless before 1989, are now joined by the vigorous poetry of the communist prisons and by the formerly prohibited authors and texts (like those of hieromonk Daniil Sandu Tudor), discovered in the past twenty years.

Although today such poetry is rejected by important literary journals, literary circles and mainstream poetry festivals, and although it is excluded from prizes and from financing for translation and publication abroad, mystagogic poetry is getting stronger and louder. The future belongs to her. Because her message cannot be exhausted, like that of postmodern, atheistic or profane poetry.

This invisible war concerned us in this study. Offering brief comments on two opposite trends in Romanian poetry from the postwar period to present, we tried to detect the human model that underpins them. For the creative act is determined, beyond the factual material and the ideas of an epoch, by the relationship of the creative ego with himself, with his fellows and with God. Ultimately, poetic creation highlights the relationship of the creative ego with the Divine Logos: a relationship either of dialogue, or corrupted by the isolationist or even sacrilegious monologue of the artist.

\section{References}

1. CRUdU, Dumitru / IANUŞ, Marius, "Manifestul Fracturist" (The Fracturist Manifesto), în Observator de Constanţa, No. 85-86/5.06.2001, http://asalt.tripod.com/a 086.htm (accesed 10.04.2017).

2. IANUȘ, Marius, "De la Fracturism la Dumnezeu", Rezumatul conferinţei ţinută la Biblioteca Bucovinei din Suceava" (From Fractusim to God. The Summary of the Conference Held at The 'Bucovina' Library from Suceava), https://yanush.wordpress.com /2012/03/16/de-la-fracturism-ladumnezeu (accesed 10.04.2017).

3. IOVĂNEL, Mihai, "Marius Ianuş, de la 'hârtie igienică' la 'fularul alb' " (Marius Ianuş, from "toilet paper" to "the white scarf"), în Cultura, no. 347/27.10.2011, http://revistacultura.ro/nou/2011/10/ marius-ianus-de-la\%E2\%80\%9Ehartie-igienica\%E2\%80\%9C-la-\%E2\%80\%9Efularulalb\%E2\%80\%9C/ (accesed 10.04.2017).

4. MINCU, Marin, "Fracturismul poetic - o negaţie neoavangardistă a 


\section{$16^{\text {th }}$ International Symposium on Science, Theology and Arts (ISSTA 2017)}

optzeciştilor" ("Poetic Fracturism - a Neo-avant-garde Negation of the Poets of the Eighties"), în Observator de Constanța, http://asalt.tripod.com /a_086.htm _accesed 10.04.2017).

5. MinElA, Claudia, "Mihai Gălăţanu îşi aniversează ziua cu prietenii, amintindu-şi” (Mihai Gălăţanu Celebrates his Birthday with Friends, Remembering), Bocancul literar, revistă de cultură online, http://www.bocancul-literar.ro/Forms/CreatieLiterara/DetaliiCreatie. aspx? id=28676 / (accesed 10.04.2017).

6. ȘTEFĂNESCU, Alex, "Mihail Gălățanu și-a pierdut răbdarea" (Mihail Gălățanu has Lost his Patience), în România Literară, no. 36/2000, http://www.romlit.ro/mihail_glanu_i-a_pierdut_rbdarea_accesed 10.04.2017). 